\title{
RESEARCH
}

Open Access

\section{Shifts in the distribution and abundance of coastal marine species along the eastern Pacific Ocean during marine heatwaves from 2013 to 2018}

Steve I. Lonhart ${ }^{*}$ (D), Rikke Jeppesen ${ }^{2}$, Rodrigo Beas-Luna ${ }^{3}$, Jeffrey A. Crooks ${ }^{4}$ and Julio Lorda ${ }^{3,4}$

\begin{abstract}
Background: Ongoing global ocean warming and a recent increase in the frequency and duration of marine heatwaves have demonstrably impacted marine ecosystems. Growing evidence points to both short- and longterm biological changes, across several levels of organization. While range shifts are among the predicted responses, few studies are focused solely on documenting such changes. Here we report ecological changes in response to marine heatwaves across multiple taxa in the eastern Pacific from central California to Baja California.

Methods: Sea surface temperature data from two estuaries and one coastal site were analyzed to define the number, duration, and intensity of marine heatwaves occurring in central and southern California from 2013 to 2018. Long-term monitoring programs and short-term research projects in coastal and estuarine ecosystems serendipitously collected specimens or photographs of extralimital species from central California to the Baja California Peninsula. Spatial and temporal sampling protocols and the targeted species for six unrelated programs varied greatly, from annual to monthly at both fixed and variable locations. In addition, anomalous occurrences were reported to staff at local and regional marine and estuarine protected areas and noted in local news and social media outlets. Anomalous range detections were categorized as range expansions and extensions, reappearances, abundance increases, shifts into new habitats, and range contractions.

Results: Multiple marine heatwaves occurred from 2014 to 2018, peaking in 2015. Marine heatwaves were more intense and longer in the estuaries, with a maximum duration of 109 days in 2015. We observed 29 species that had responded to the warm water anomalies of 2014-2018 along the eastern Pacific Ocean between central California and the Baja California Peninsula: 7 expansions, 2 extensions, 10 reappearances, 7 increases, 2 shifts into new habitats, and 1 apparent contraction. These shifts included algae, invertebrates and fishes. Twenty species were observed by professional biologists involved both in long-term monitoring programs and short-term studies, 6 by amateur naturalists as part of community-based science programs in the field, and 3 through a combination of all three.

(Continued on next page)
\end{abstract}

\footnotetext{
* Correspondence: steve.lonhart@noaa.gov

'Monterey Bay National Marine Sanctuary, National Ocean Service, NOAA.

110 McAllister Way, Santa Cruz, CA 95060, USA

Full list of author information is available at the end of the article
}

(c) The Author(s). 2019 Open Access This article is distributed under the terms of the Creative Commons Attribution 4.0 International License (http://creativecommons.org/licenses/by/4.0/), which permits unrestricted use, distribution, and reproduction in any medium, provided you give appropriate credit to the original author(s) and the source, provide a link to the Creative Commons license, and indicate if changes were made. The Creative Commons Public Domain Dedication waiver (http://creativecommons.org/publicdomain/zero/1.0/) applies to the data made available in this article, unless otherwise stated. 
(Continued from previous page)

Conclusions: Increased warm waters, sustained for an unprecedented 4 of 5 years, facilitated the northward redistribution of multiple species from several taxonomic groups. Species shifting northward were from warmtemperate and subtropical ecosystems to the south. In the absence of programs designed to detect range shifts, we must rely on the serendipitous observations of biologists conducting both long-term monitoring and short-term research, and the growing wealth of information from community-based science programs made available via online databases.

Keywords: Range shift, Expansion, Extension, El Niño, Climate change, Warm water anomalies, Marine heatwave

\section{Background}

Global ocean warming and rapid responses to climate change have altered the pace, scale and dynamics of species' ranges (Pinsky et al. 2013). Growing evidence indicates global ocean warming and extreme heating events drive the redistribution of species (Smale et al. 2019) and may negatively affect biodiversity, ecosystem services, and marine economies (Bonebrake et al. 2018). Ongoing efforts focus on understanding the effects of increased ocean temperature on population dynamics (Donelson et al. 2019), habitat use, ecological interactions (e.g., Bartley et al. 2019), environmental processes, and human dependencies ( $\mathrm{Pecl}$ et al. 2017).

In the past two decades, marine heatwaves (MHWs) periodic, anomalously high ocean temperatures (Hobday et al. 2018) - have increased in both frequency and intensity at regional and local scales (Frölicher et al. 2018). In contrast to the slow, gradual rise of ocean temperatures associated with global warming, MHWs are discrete periods ( 5 days to months) when temperatures are in the 90th percentile relative to the mean climatology (Hobday et al. 2016). Species redistributions resulting from both climate change and MHWs vary spatially and temporally, often in idiosyncratic and unpredictable ways (Hiscock et al. 2004; Gilman et al. 2010).

In marine ecosystems, pelagic larvae of benthic species can be transported beyond typical range endpoints during atypical circulation events that can co-occur with warm water anomalies (Gaylord and Gaines 2000). Along the eastern Pacific of North America, warm-temperate and subtropical species move poleward during short-term warm water anomalies, such as an El Niño Southern Oscillation (ENSO) event (Lonhart and Tupen 2001; Lonhart 2009). Counter-currents develop and flow poleward for several months during an ENSO event, dispersing low-latitude larvae and adults beyond their normal geographic range (Zacherl et al. 2003; Cavole et al. 2016; Feeney and Lea 2016; Goddard et al. 2016). Like ENSO events, particularly long MHWs can increase poleward flow of coastal currents and sustain abnormally high temperatures, both of which contribute to movement of coastal marine species from low to high latitudes (Sanford et al. 2019).
Range records, which are key to tracking species redistributions, represent observations of a species in both space and time, and a collection of range records describes the geographic range of a species (Gaston 2009). Ideally these records represent live specimen collections that are deposited as vouchers in a museum collection where they are curated in perpetuity. However, it is not always feasible to collect specimens, and it is increasingly common to both use newer types of evidence for range records, such as photographs, video, sound recordings, and unpublished personal observations, and to use new methods, such as social media (Di Minin et al. 2015) and web-based databases (Beas-Luna et al. 2014). Indeed, the ubiquity of digital cameras and access to large databases and computing networks allow amateur naturalists to rapidly share digital media, which can result in species identifications by experts (Dickinson et al. 2010). Furthermore, new range records are often obtained serendipitously, as the by-product of research not necessarily focused on characterizing the geographic range of a particular species, and in many cases through the efforts of community-based science programs, which contribute significantly to biological studies of global climate change (Dickinson et al. 2012). For example, monitoring programs deploying field biologists at regular intervals in fixed locations, such as marine protected areas, can increase the likelihood of observing species redistributions as they occur.

From 2013 to 2015 the northeastern Pacific experienced the largest marine heatwave on record (Di Lorenzo and Mantua 2016), which was driven by a persistent atmospheric ridge and resulted in a large-scale warm water anomaly commonly referred to as the 'Blob' (Bond et al. 2015). As the Blob diminished, an ENSO event occurred in 2016, and the combination created an unprecedented warm water anomaly that lasted 3 years, during which there were multiple MHWs. A broad spectrum of taxa was impacted by these events, including 34 species listed by Cavole et al. (2016) in Alaska and Washington and 67 species listed by Sanford et al. (2019) in northern California and Oregon. Complementing the efforts of Cavole et al. (2016) and Sanford et al. 
(2019) at higher latitudes, we report new range records, localized increases, or occupancy of new habitats by 29 marine species either in an estuary or along the open coast of central and southern California, USA and Baja California and Baja California Sur, México.

\section{Methods}

\section{Study region}

Data collections ranged between Monterey Bay, California in the north and Isla Magdalena, Baja California Sur, México in the south, covering $>3800 \mathrm{~km}$ of coastline (Fig. 1) . Observations span three major biogeographical provinces (Valentine 1966): the cold-temperate Oregonian (southeastern Alaska to Point Conception, California), the warmtemperate Californian (Point Conception to Punta Eugenia, Baja California Sur) and the sub-tropical Surian (Punta Eugenia to Cabo San Lucas). The three biogeographic provinces are separated by two important biogeographic boundaries: Point Conception separates Oregonian from Californian biota, and Punta Eugenia separates Californian from Surian biota (Valentine 1966).

Due to the large latitudinal extent ( $38^{\circ}$ to $23^{\circ}$ north), the study region spans multiple ecosystems, (e.g., open coast, bays and estuaries) and different thermal regimes (cold-temperate, warm-temperate, and sub-tropical) (Blanchette et al. 2008). We focused on kelp forests and estuaries, both studied as part of pre-existing, long-term monitoring (LTM) programs primarily associated with designated protected areas. Nearshore subtidal reefs support extensive kelp forests along the coast of California and into Baja California, particularly at upwelling centers, where cooler temperatures support cold-temperate communities of giant kelp, Macrocystis pyrifera, and other kelps (Edwards and Hernández-Carmona 2005). Several kelp forests within the study area are the subject of intensive subtidal studies (Beas et al. in prep.), particularly within California's extensive network of statedesignated marine protected areas (MPAs), which are themselves nested within various Federal MPAs, including national marine sanctuaries.

California estuaries within the National Estuarine Research Reserve (NERR) system were designated to protect and study estuarine ecosystems. The Elkhorn Slough NERR is a small estuary $\left(182 \mathrm{~km}^{2}\right)$ in central California that has experienced extensive modification through historic and on-going land use practices (Caffrey et al. 2002). It contains multiple habitats, such as mudflats, eelgrass beds, tidal channels, and salt marsh, all supporting a diverse array of plants, algae, and animals. In contrast, the Tijuana River NERR is a medium size $\left(9.2 \mathrm{~km}^{2}\right)$ coastal wetland in southern California between the cities of San Diego, California and Tijuana, Baja California, México. Although the reserve is in a highly urbanized setting, it supports extensive salt marsh habitat, home to several rare or endangered bird species (Zedler et al. 1992). Both NERR sites have several LTM programs to collect environmental data and to track the diversity and abundance of key invertebrate taxa, including rare species, and identify potentially invasive species.

\section{Local oceanography}

Sea surface temperature (SST) data were obtained from both the Elkhorn Slough and Tijuana River NERR sites, which are part of a network of state-federal protected

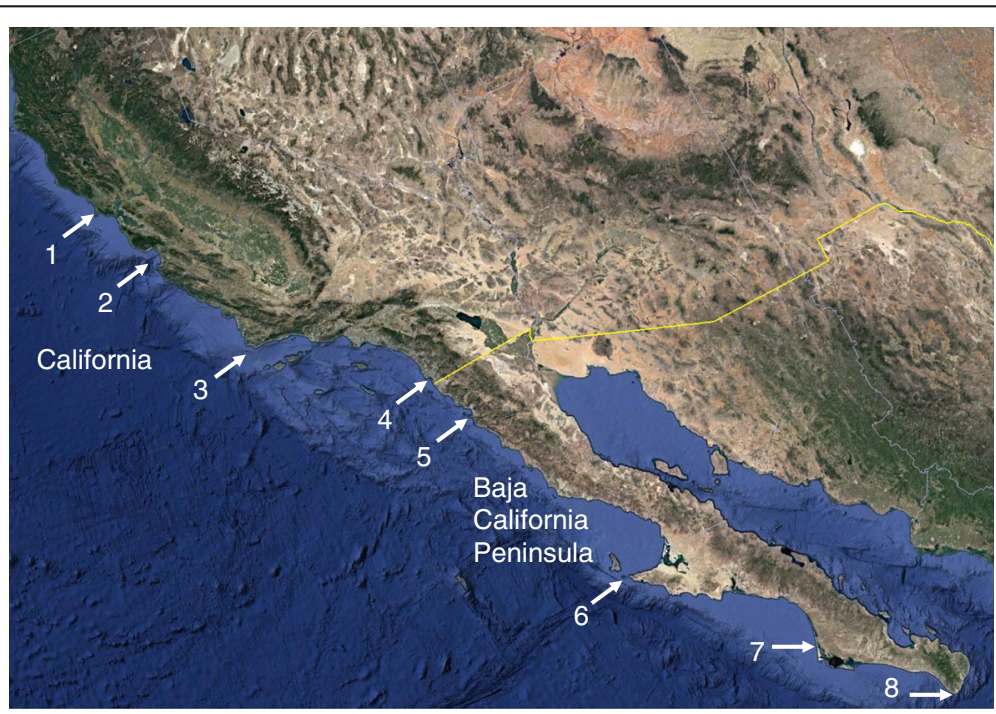

Fig. 1 Coastline of California, USA and Baja California Peninsula, México. Locations include (1) Tomales Bay, (2) Monterey Bay, which includes Elkhorn Slough National Estuarine Research Reserve (NERR) and Hopkins Marine Station, (3) Point Conception, (4) San Diego Bay and Tijuana River NERR, (5) Bahia de Todos Santos, (6) Punta Eugenia, (7) Isla Magdalena, and (8) Cabo San Lucas. Species were observed primarily between locations 2 and 7, spanning over $3800 \mathrm{~km}$ of coastline 
areas collecting environmental data in an identical manner and available to the public (http://cdmo.baruch.sc. edu/). Daily SST data at the NERR sites were recorded by in situ temperature loggers placed $30 \mathrm{~cm}$ above the benthos and $0.5-1.5 \mathrm{~m}$ below local mean lower low water, sampling at $15 \mathrm{~min}$ intervals; these data were averaged to generate a daily value. In contrast, SST is measured once daily at Hopkins Marine Station (HMS) using sea water collected from shore. HMS was centrally located for many of the coastal observations made in central CA, and has the most extensive SST data set, which is available from Stanford University's Marine Life Observatory (http://mlo. stanford.edu/sst.htm). The length of recorded daily temperature varied by location: ESNERR (March 20012018), HMS (1919-2018), and TRNERR (2005-Dec 2018). Data were evaluated, converting notations indicating "no data" into blanks and deleting anomalously high values (> $3{ }^{\circ} \mathrm{C}$ relative to readings before and after). Similar SST data for Baja California either were unavailable or too short in duration ( $<5$ years).

Hobday et al. (2016) recommend using at least 30 years of data (if available) to generate a baseline climatology. We created a climatology at each site using data from the initial collection date through the end of 2012: 12, 94, and 8 years for ESNERR, HMS, and TRNERR, respectively. Characterization of MHWs followed standardized methods (Hobday et al. 2016) at each site: 1) climatology data were used to calculate the 90th percentile threshold value, 2) MHWs had to persist $\geq 5$ days continuously above the threshold, and 3) a discrete MHW required that any gaps (i.e. days below the threshold) between events were $\leq 2$ days and subsequent events were $\geq 5$ days above the threshold. We calculated for each year from 2013 to 2018 several of their suggested MHW metrics, including the number of MHWs, duration of each MHW, maximum observed anomaly each year, and a sum of daily anomalies during all MHWs $\left({ }^{\circ} \mathrm{C}\right.$ days). In addition, each year we calculated the number of anomalous days above the threshold excluding MHW days and the range of MHW duration.

Selected SST data were visualized either as monthly anomalies from the long-term mean or as daily values for an entire calendar year. Monthly anomaly values for ESNERR and TRNERR were generated via the NERR online database (www.swmprats.net), which averaged daily values within each month; a similar system was not available for the HMS data. For a given year, observed SSTs were plotted with the climatology and the 90th percentile threshold value (Hobday et al. 2016) for ESNERR, HMS, and TRNERR data sets.

\section{Field observations}

Species observations were collected serendipitously by professional biologists during ongoing research programs, including place-based, LTM programs associated with protected areas; short-term research (STR) projects, including chance discoveries during unstructured site visits; and by amateur naturalists involved with communitybased science (CBS) programs, reporting data via digital media. In all cases, biologists, trained observers, and amateurs alike encountered these species while conducting activities unrelated to the science of range shift ecology.

Kelp forest monitoring programs include the Partnership for Interdisciplinary Studies of Coastal Oceans (PISCO), Monitoring Ecosystems Across the Californias (MexCal), and two partnerships between México and Stanford University: Community and Biodiversity (COBI) and Coupled Natural Human Systems (CNH). PISCO was established in 1999 as a scientific program led by scientists from four universities in Oregon and California, conducting long-term and large-scale studies to understand the functioning of the coastal marine ecosystem along the U.S. west coast. PISCO at University of California, Santa Cruz conducts annual subtidal reef surveys at 50-100 fixed sites throughout central California, emphasizing the Monterey Bay coastal region (piscoweb. org). PISCO divers are trained to identify and count targeted species, but also notice anomalies. At each site, two divers survey two $30-\mathrm{m}$ long transects, $2 \mathrm{~m}$ wide, at three depths $(5,12.5$, and $20 \mathrm{~m})$, counting mobile invertebrates $>2.5 \mathrm{~cm}$, targeted algal species, and percent cover of attached invertebrates and algae. Fish surveys consist of three $30-\mathrm{m}$ long benthic transects, $2 \mathrm{~m}$ wide and high, at four depths $(5,10,15$, and $20 \mathrm{~m})$ and include all species except for cryptic species and those whose adult size is $<10 \mathrm{~cm}$ total length. MexCal is based at Universidad Autónoma de Baja California (UABC) and is a multidisciplinary group of researchers, students and fishers that began in 2011 to monitor kelp forest, rocky intertidal, and coastal lagoon communities in northern Baja California (https://mex-cal.org/) using the same methods as PISCO. COBI and $\mathrm{CNH}$ are community-based monitoring programs involving a Mexican civil association (Comunidad y Biodiversidad A.C.) and three fishing cooperatives distributed along Baja California Peninsula (Cooperativa Ensenada at El Rosario Baja California; Coperativa Buzos y Pescadores de Isla Natividad at Isla Natividad; and Cooperativa el Progreso at La Bocana, Baja California Sur). Since 2006, California Reef Check staff has trained fishers and their families to annually monitor marine reserves and reference sites around their concessioned fishing grounds, using a subset of PISCO methods.

Estuarine monitoring programs occur at both NERR sites (Elkhorn Slough and Tijuana River), where staff researchers are regularly in the field, providing opportunities to observe recent changes in diversity and abundance. Pertaining to the observations reported in 
this study, ESNERR staff scientists sample two sites annually (October-November) using 15 crab traps deployed for $24 \mathrm{~h}$ at each site. Sampling within TRNERR began in 1986 for the Tijuana River Estuary and Los Peñasquitos Lagoon, and in the extreme end of south San Diego Bay in 2012. For each of these three systems, core monitoring includes water quality and weather (continuously-deployed dataloggers), vegetation (annual transect sampling), nekton (annual seine sampling), minnow traps (bi-monthly), and sediment cores for large invertebrates (annually) at four to six sampling sites per system.

Additional, ancillary observations of some species were either noted by the authors during STR projects or reported to us by others via digital media (e.g., news, online databases). These chance discoveries occurred at all times of the year throughout the study region. We also accessed an online community-based science resource, iNaturalist (www.inaturalist.org), which serves observational data collected by amateur naturalists and verified by taxonomic experts.

\section{Range information}

For each record we include specific location data (decimal degrees) and the date observed, as both are important factors when making comparisons to historical data (Tingley and Beissinger 2009) and for future meta-analyses (Przeslawski et al. 2012). We include all new records to increase the probability associated with detecting actual occupancy (Tingley and Beissinger 2009): multiple records over a short time period are more valuable than a single record of presence-only data, particularly when comparing current observations to historic occurrences.

We used multiple sources to determine the current geographic range of each species, including peerreviewed publications, published field guides, museum records, expert opinion and community-based science databases. Museum records were accessed at the California Academy of Sciences (CAS, http://researcharchive. calacademy.org/research/izg/iz_coll_db/index.asp) and community-based science observations were accessed through iNaturalist, an application hosted by the CAS. Przeslawski et al. (2012) suggest community-based science programs coupled with museum records and expert opinion can provide the necessary capacity to accurately detect and describe recent range shifts. Note, however, that published range data may not reflect the current range of a species, since ranges constantly fluctuate and, until recently, such information was infrequently published or updated.

We describe each new record in terms of its type, source, and method used for detection. Record types include voucher specimens deposited in a museum collection, photographs and video, data (e.g., counts from LTM programs), and expert opinion. Records were reported by LTM, STR, and CBS programs, digital media, and experts in the field. Many methods were used to capture these species (often inadvertently): surveys, fishing, trapping, and expeditions in the field unrelated to range shift ecology.

For each species we categorized six different types of range shift. 1) A range extension involves detecting a species in an area where it already occurs but previously had been undetected, likely due to sampling artifacts (e.g., rarity, crypsis, under-sampling). 2) A range expansion occurs when a species moves into an area it had not previously occupied and is subsequently detected. This subtle distinction between expansions and extensions is focused on the timing of detection: range expansions are detected as they occur, whereas range extensions are delayed detections of past expansions. 3) A reappearance indicates the species is within its known range (near its northern limit) but has been absent. 4) An increase reflects a change from low to higher densities. 5) A habitat shift was within the published range but the observed record was in a new habitat that was previously unoccupied. 6) Contraction indicates an absence of observations at multiple locations and spanning multiple years (in this case, near the southern range limit).

Based on life history characteristics of the species, its local history, and current abundance, we predict whether each species is expected to persist or not, and categorize the stage of range shift as defined by Bates et al. (2014): arrival, population increase, or persistence. We also include a "transient" category to denote species that had reappeared, placing it between arrival and population increase. A level of confidence (low, moderate or high) based on our knowledge of the species and its local spatial extent is also included.

Nomenclatural conventions follow those used by the World Register of Marine Species (www.marinespecies. org), and when possible, a common name provided. The published northern and southern range endpoints are listed. For locations in the United States and México we use abbreviations for California (CA), Oregon (OR), and Baja California (BC) and Baja California Sur (BCS), and for other international locations we list city and country, as available. The type of range change is listed and a new range endpoint (decimal degrees), as appropriate. Comments providing context to the new records, including details on when and where individuals were captured, photographed, or observed, are in the Additional file 1.

\section{Results}

\section{Local oceanography}

Monthly temperature anomalies in the estuaries were continuously above the long-term mean from 2014 through 2016, representing the longest and most 
dramatic increase in SST at these sites since SSTs were first monitored (Fig. 2). Daily SST data were used to delineate MHWs, and multiple occurred each year from 2013 to 2018 in central and southern California, except at HMS in 2013 (Table 1); these findings extend the warm water event through 2018. Both estuarine sites (ESNERR and TRNERR) had more MHWs than the open coast site (HMS) in Monterey Bay (34, 21, and 46, respectively). The individual duration of MHWs varied from 5 days (the defined minimum) to 109 days, which occurred at TRNERR in 2015. The longest individual MHW occurred in 2015 at each of the three sites (Table 1 ), as did the highest ${ }^{\circ} \mathrm{C}$ days, a cumulative measure of heat intensity. In 2015 TRNERR experienced $463.8^{\circ} \mathrm{C}$ days, double that of ESNERR (219.8) and triple HMS (143.2). The 2015 MHWs were most frequent
January-March and again July-October (Fig. 3). After a relatively cool 2017, the number of MHWs increased at the NERR sites in 2018, particularly for TRNERR, which had 12 MHWs lasting a total of 177 days and a cumulative intensity $250^{\circ} \mathrm{C}$ days, its 3rd highest intensity behind 2014 and 2015 (Table 1).

Not all anomalous temperatures meet the criteria for being included in discrete MHWs. We noted for each year from 2013 to 2018 the number of days above the 90th percentile threshold that were non-MHW anomalies (Table 1). In 2013, which was not part of the warm water event in central and southern CA based on our results (Fig. 2), the average number of non-MHW anomaly days (17 days; averaged across sites) was greater than MHW days (12 days). With one exception (HMS in 2017), total number of MHW days consistently exceeded

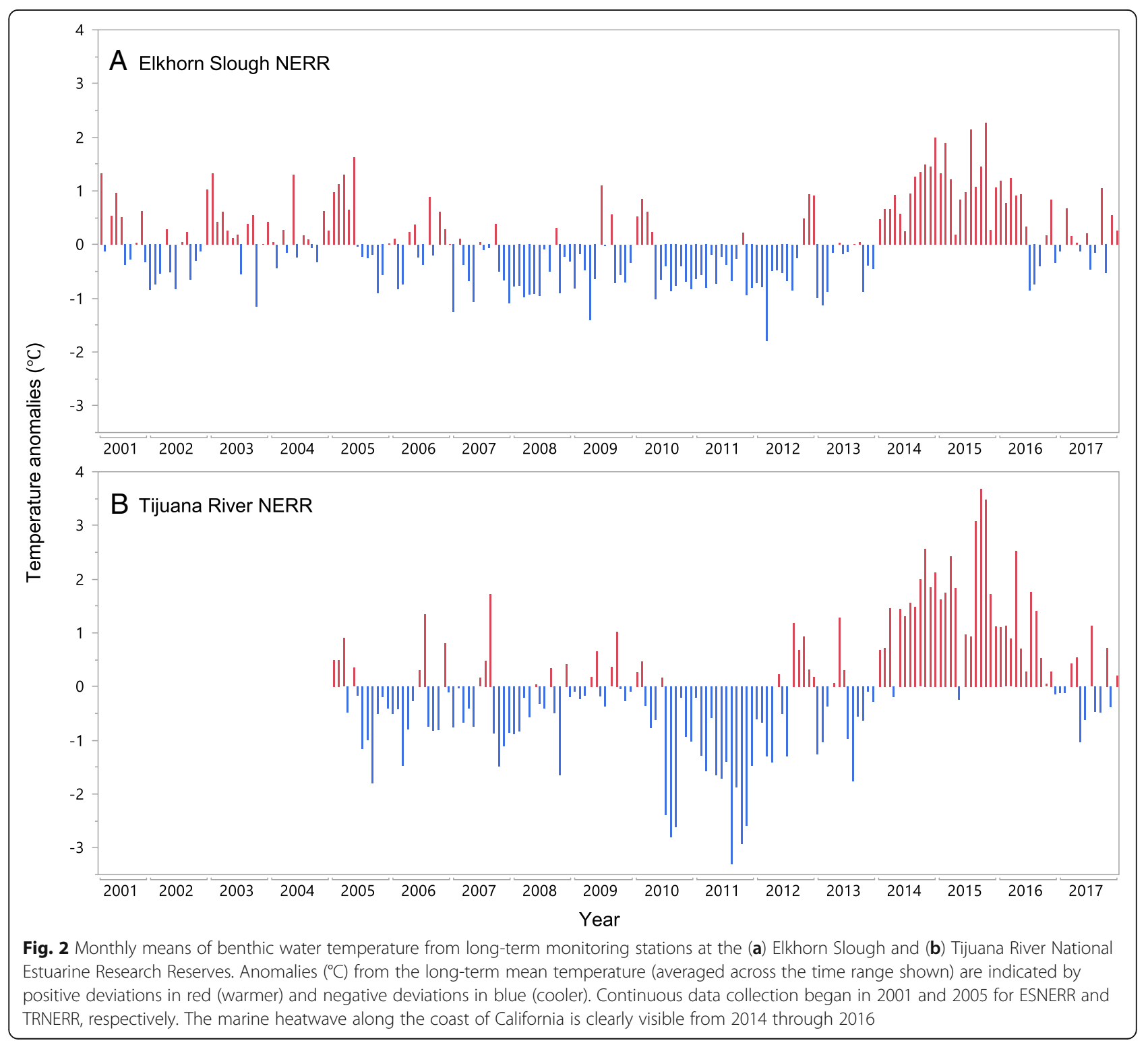


Table 1 Metrics to characterize marine heatwaves (MHWs) for each year at three sites. Number of MHWs, total duration of all MHWs in a year, maximum observed anomaly above the threshold during a MHW, and the sum of daily intensity anomalies $\left({ }^{\circ} \mathrm{C}\right.$ days) follow Hobday et al. (2016). Also provided are the number of anomalous days exceeding the 90th percentile threshold value but not meeting the criteria for inclusion as part of a MHW (i.e. non-MHW days) and the range of MHW duration

\begin{tabular}{|c|c|c|c|c|c|c|c|}
\hline \multirow[t]{2}{*}{ Site } & \multirow[b]{2}{*}{ Year } & \multirow{2}{*}{$\begin{array}{l}\text { No. of } \\
\text { MHWs }\end{array}$} & \multirow{2}{*}{$\begin{array}{l}\text { Total duration } \\
\text { MHWs (d) }\end{array}$} & \multirow{2}{*}{$\begin{array}{l}\text { Non-MHW } \\
\text { anomalies (d) }\end{array}$} & \multirow{2}{*}{$\begin{array}{l}\text { MHW } \\
\text { range (d) }\end{array}$} & \multirow{2}{*}{$\begin{array}{l}\text { Max. deviation } \\
\text { MHW }\left({ }^{\circ} \mathrm{C}\right)\end{array}$} & \multirow[b]{2}{*}{${ }^{\circ} \mathrm{C}$ days } \\
\hline & & & & & & & \\
\hline \multirow[t]{6}{*}{ ESNERR } & 2013 & 2 & 11 & 17 & $5-6$ & 1.1 & 5.4 \\
\hline & 2014 & 6 & 121 & 37 & $10-41$ & 3.0 & 122.1 \\
\hline & 2015 & 10 & 206 & 26 & $8-55$ & 3.1 & 219.8 \\
\hline & 2016 & 9 & 105 & 15 & $5-21$ & 1.5 & 60.7 \\
\hline & 2017 & 3 & 45 & 17 & $9-25$ & 1.7 & 25.8 \\
\hline & 2018 & 6 & 113 & 26 & 6-39 & 2.9 & 107.5 \\
\hline \multirow[t]{6}{*}{ HMS } & 2013 & 0 & 0 & 1 & 0 & 0.2 & 0.0 \\
\hline & 2014 & 5 & 114 & 32 & $16-30$ & 2.4 & 121.7 \\
\hline & 2015 & 6 & 151 & 22 & $5-58$ & 2.5 & 143.2 \\
\hline & 2016 & 3 & 18 & 70 & $5-8$ & 0.9 & 7.4 \\
\hline & 2017 & 2 & 30 & 18 & $8-22$ & 2.8 & 33.4 \\
\hline & 2018 & 5 & 61 & 25 & 6-19 & 2.2 & 42.7 \\
\hline \multirow[t]{6}{*}{ TRNERR } & 2013 & 3 & 25 & 32 & 5-14 & 1.6 & 17.9 \\
\hline & 2014 & 11 & 233 & 26 & $5-78$ & 4.1 & 280.9 \\
\hline & 2015 & 8 & 259 & 11 & 5-109 & 5.2 & 463.8 \\
\hline & 2016 & 9 & 145 & 30 & $5-37$ & 5.1 & 209.1 \\
\hline & 2017 & 6 & 54 & 48 & 5-16 & 5.2 & 58.3 \\
\hline & 2018 & 12 & 177 & 20 & $5-32$ & 3.8 & 250.0 \\
\hline
\end{tabular}

non-MHW days from 2014 to 2018 (Table 1). For all years and at all three sites, the maximum anomaly above the threshold always occurred during one of the designated MHWs.

The total number of anomalous days above the 90th percentile threshold in 2013 was 28,1 , and 57 and in 2017 was 62, 48, and 102 for ESNERR, HMS, and TRNERR, respectively. During the warm years (2014-16, 2018) total days above the threshold averaged 162, 123, and 225 for ESNERR, HMS, and TRNERR, respectively.

\section{Field observations and range information}

We recorded 29 species that responded to the warm water anomalies of 2013-2018 along central and southern California and the western Baja California Peninsula (Table 2). The published range, the observed change, and comments on the discovery of each species are provided in the Additional file 1. We report 7 range expansions, 2 range extensions, 10 reappearances, 7 abundance increases, 2 shifts into new habitats, and 1 range contraction (Table 3).

Seven species established new range records north of their previous known range endpoints. Of the seven northern range expansions, three were crabs (Achelous xantusii and Malacoplax californiensis, and Uca princeps), two mollusks (Aplysia vaccaria and Lobatus galeatus), one urchin (Arbacia stellata), and one fish (Alphestes immaculatus). The average range expansion was $390 \mathrm{~km}$, ranging from $25 \mathrm{~km}$ for $A$. vaccaria to about $580 \mathrm{~km}$ for both A. immaculatus and L. galeatus (Table 2). Two species, the heart urchin Lovenia cordiformis and an annelid worm Spirobranchus spinosus, were considered northern range extensions, moving $378 \mathrm{~km}$ and $16 \mathrm{~km}$ northward, respectively.

Ten reappearances included four fish (Balistes polylepis, Ctenogobius sagittula, Hypsypops rubicundus and Sphoeroides annulatus), two crustaceans (Callinectes arcuatus and Farfantepenaeus californiensis), one brachiopod (Glottidia albida), one kelp (Laminaria farlowii), one sea cucumber (Leptosynapta albicans), and one cnidarian (Phyllorhiza punctata). Except for the brachiopod and sea cucumber, these reappearances are expected to be short in duration (Table 3). Quantitative data collected by the LTM PISCO program in central CA for $L$. farlowii show a rapid increase in 2015, the warmest year along the open coast, then a decline in 2016 and its disappearance since then (Fig. 4).

Seven species increased in abundance. Three fish species (Chromis punctipinnis, Paralabrax clathratus, and Semicossyphus pulcher), one nudibranch (Felimida macfarlandi) and one whelk (Kelletia kelletii) are typical of warm-temperate and subtropical regions in southern CA and Baja California, respectively. Adults of these five 

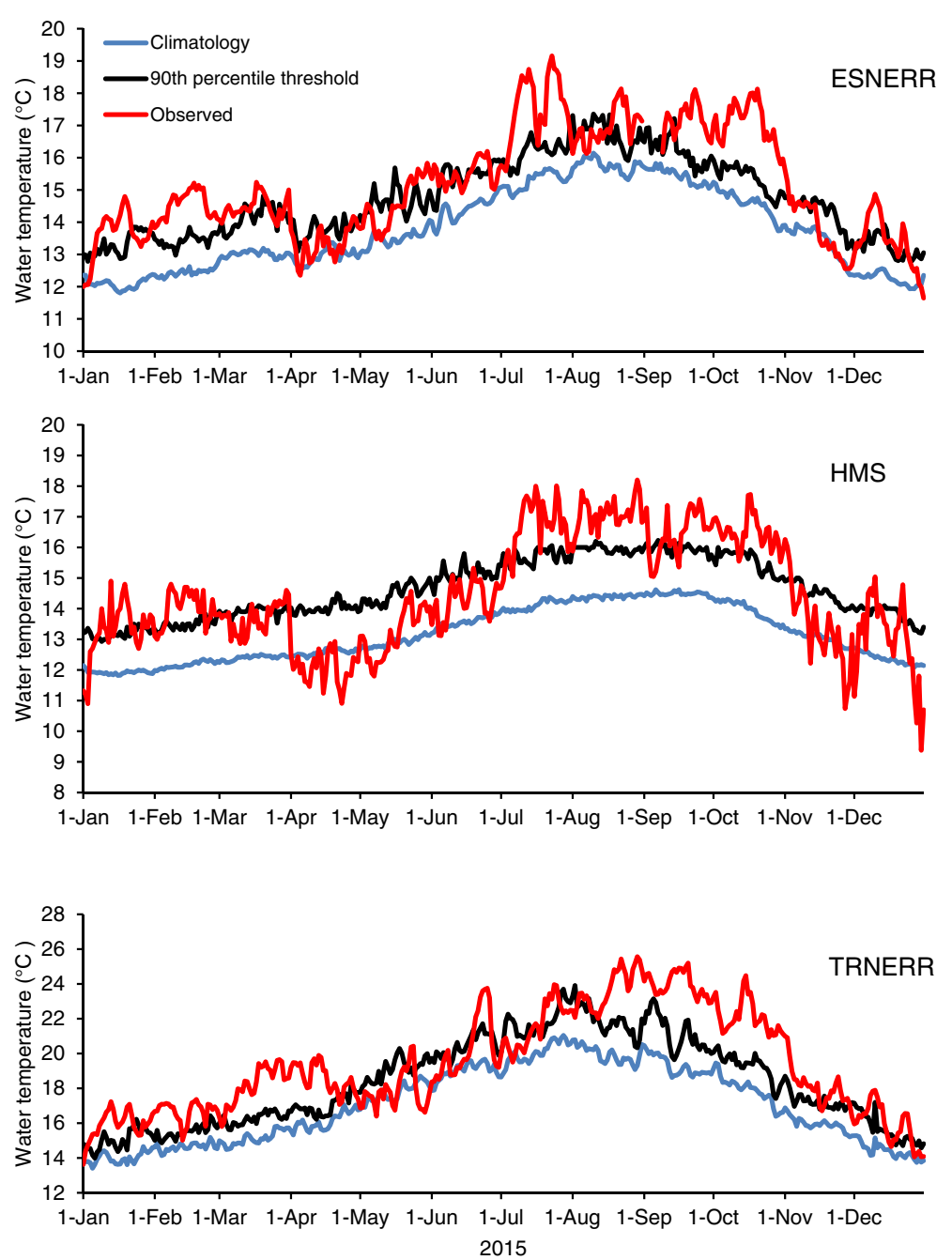

Fig. 3 SST climatology (blue; long-term mean prior to 2013), 90th percentile MHW threshold SST (black), and 2015 observed SST (red) at ESNERR (top), HMS (middle), and TRNERR (bottom). MHWs occur when the observed SST is above the threshold for $\geq 5$ days

species are rare north of Point Conception, and offspring are absent except during warm water events, when young-of-the-year and juveniles increase. Except for $F$. macfarlandi, which is short-lived, these species remain abundant in central CA, albeit as older age classes, through early 2019. Observations of white urchins (Lytechinus pictus) were delayed and mostly of adults due to the cryptic nature of newly settled individuals and slow growth. The sea hare Aplysia californica, which is targeted by PISCO in central CA, was rare or absent on transects in the 2000s but increased noticeably from 2013 to 2015, then rapidly declined from 2016 to 2018 (Fig. 5).

A nudibranch (Flabellina iodinea) and mantis shrimp (Pseudosquillopsis marmorata) were both found in the estuarine habitat of ESNERR. The nudibranch is rare along the open coast, and is not expected to persist. The mantis shrimp is more commonly found in embayments, and two individuals were trapped at ESNERR, one in 2011 prior to the warm water event, and one in 2016.

One species of fish (Medialuna californiensis) appears to be absent from a large portion of its southern range along the tip of the Baja Peninsula, which may represent the initiation of a range contraction (currently $-765 \mathrm{~km}$ ) . Survey data from both sides of the Baja Peninsula indicate it has been seen once since 2006 in the southern part of its range.

Professional biologists involved with LTM and STR (or both) accounted for 20 of the observations (Table 3). Amateur naturalists and citizen scientists involved with CBS accounted for 6 observations, and the remaining combinations of LTM, STR and CBS accounted for 3 observations. 
Table 2 Existing and new range limits for all 29 species. Distances were determined using a Google Earth measuring tool by connecting a straight line from former to current range endpoint

\begin{tabular}{|c|c|c|c|c|c|}
\hline Genus & species & Northern limit & Southern limit & New range record & Shift $(\mathrm{km})$ \\
\hline Achelous & xantusii & Morro Bay, CA & Punta Piaxtla, MX & Tomales Bay, CA & 370 \\
\hline Alphestes & immaculatus & Golfo de California, MX & Islas Galápagos, Ecuador & La Bocana, BCS & 577 \\
\hline Aplysia & californica & Yaquina Bay, OR & El Salvador & & \\
\hline Aplysia & vaccaria & Monterey Bay, CA & Golfo de California, MX & Elkhorn Slough, CA & 25 \\
\hline Arbacia & stellata & Channel Islands, CA & Perú & Monterey, CA & 362 \\
\hline Balistes & polylepis & Alaska & Chile & & \\
\hline Callinectes & arcuatus & San Francisco Bay, CA & Chile & & \\
\hline Chromis & punctipinnis & Monterey, CA & Punta San Pablo, Baja CA, MX & & \\
\hline Ctenogobius & sagittula & Los Peñasquitos Lagoon, CA & Perú & & \\
\hline Farfantepenaeus & californiensis & San Francisco Bay, CA & Callao, Perú and Galápagos Islands & & \\
\hline Felimida & macfarlandi & Monterey, CA & Baja CA, MX & & \\
\hline Flabellina & iodinea & Vancouver Is., Canada & Islas Galápagos, Ecuador & & \\
\hline Glottidia & albida & Monterey Bay, CA & Golfo de Nicoya, Costa Rica & & \\
\hline Hypsypops & rubicundus & Monterey Bay, CA & Southwestern Gulf of CA, MX & & \\
\hline Kelletia & kelletii & Monterey, CA & Isla Asuncion, Baja CA, MX & & \\
\hline Laminaria & farlowii & British Columbia, Canada & Bahia del Rosario, Baja CA, MX & & \\
\hline Leptosynapta & albicans & Bodega Head, CA & Baja CA, MX & & \\
\hline Lobatus & galeatus & Golfo de California, MX & Perú & La Bocana, BCS & 580 \\
\hline Lovenia & cordiformis & Point Conception, CA & Peru & Monterey, CA & 378 \\
\hline Lytechinus & pictus & Monterey, CA & Ecuador & & \\
\hline Malacoplax & californiensis & Morro Bay, CA & Golfo Dulce, Costa Rica & Elkhorn Slough, CA & 212 \\
\hline Medialuna & californiensis & Vancouver, Canada & Golfo de California, MX & El Rosario, BC & -765 \\
\hline Paralabrax & clathratus & Columbia River, OR & Bahia Magdalena, Baja CA, MX & & \\
\hline Phyllorhiza & punctata & San Diego Bay, CA & Golfo de California, MX & & \\
\hline Pseudosquillopsis & marmorata & Tomales Bay, CA & Islas Galápagos, Ecuador & & \\
\hline Semicossyphus & pulcher & Monterey Bay, CA & Golfo de California, MX & & \\
\hline Sphoeroides & annulatus & Redodndo Beach, CA & Pisco, Perú & & \\
\hline Spirobranchus & spinosus & Carmel, CA & Baja CA, MX & Pacific Grove, CA & 16 \\
\hline Uca & princeps & Ensenada, MX & Peru & Huntington Beach, CA & 240 \\
\hline
\end{tabular}

\section{Discussion}

\section{Local oceanography}

SST data from two locations in central California and one in southern California displayed similar climatological means and patterns of MHWs. The record-setting warm water event from 2014 to 2016 (Jacox et al. 2018) was clearly evident in our analyses (Fig. 2; Table 1). In addition, we present local patterns - cooling in central and southern CA for 2017, then warming in mid-2018, especially in a southern California estuary - that match large-scale patterns observed in the California Current ecosystem (Thompson et al. 2018). The number, duration and frequency of MHWs and non-MHW anomalous days was particularly high in the estuarine systems of central and southern CA. Engineering solutions have altered tidal flow at these two NERR sites, with each site relying on a sill to dampen tidal scour. Shallow by nature and modified to increase water residence time, it was not surprising that the NERR sites were warmer than the open coast site, and that TRNERR in southern CA was warmer than ESNERR in central CA.

Identifying MHWs using standardized methods (Hobday et al. 2016) is a useful tool, but it is also limited. In 2016 the NERR sites averaged 125 MHW days and HMS had 18 MHW days. Using only MHW days to describe the thermal anomalies was misleading, largely due to the requirement that a MHW is $\geq 5$ days. HMS in 2016 experienced six 4-day events and two 3-day events, with 70 non-MHW days above the threshold in total. Plots displaying deviations from the climatological mean (e.g., Fig. 2), which are common, and plots of MHWs (e.g., 
Table 3 Summary of source material, range shift type, and perceived persistence and status for all 29 species

\begin{tabular}{|c|c|c|c|c|c|c|c|c|}
\hline Genus & species & Record type & Record Source & Method & $\begin{array}{l}\text { Range shift } \\
\text { type }\end{array}$ & Persistence & Bates' stage & Confidence \\
\hline Achelous & xantusii & Photos & ESNERR, expert & LTM, STR & Expansion & Short & Arrival & High \\
\hline Alphestes & immaculatus & Data & $\mathrm{CNH}$ & CBS & Expansion & Short & Arrival & Moderate \\
\hline Aplysia & californica & Data & PISCO & LTM, STR & Increase & Long & Persistence & High \\
\hline Aplysia & vaccaria & Photos & $\begin{array}{l}\text { Blue Water } \\
\text { Ventures }\end{array}$ & CBS & Expansion & Short & Arrival & Moderate \\
\hline Arbacia & stellata & $\begin{array}{l}\text { CASIZ \#206961, data, } \\
\text { photos }\end{array}$ & $\begin{array}{l}\text { PISCO, MexCal, } \\
\text { CNH }\end{array}$ & LTM, CBS & Expansion & Short & Arrival & High \\
\hline Balistes & polylepis & Photos & Newspaper & CBS & Reappearance & Short & Transient & High \\
\hline Callinectes & arcuatus & Data & TRNERR & LTM & Reappearance & Short & Transient & Moderate \\
\hline Chromis & punctipinnis & Photos & Expert & STR & Increase & Short & $\begin{array}{l}\text { Population } \\
\text { increase }\end{array}$ & High \\
\hline Ctenogobius & sagittula & Data & TRNERR & LTM & Reappearance & Short & Transient & High \\
\hline Farfantepenaeus & californiensis & Data & TRNERR & LTM & Reappearance & Short & Transient & High \\
\hline Felimida & macfarlandi & Photos & Expert & STR & Increase & Short & $\begin{array}{l}\text { Population } \\
\text { increase }\end{array}$ & Moderate \\
\hline Flabellina & iodinea & Expert opinion & Expert & STR & New habitat & Short & $\begin{array}{l}\text { Population } \\
\text { increase }\end{array}$ & High \\
\hline Glottidia & albida & Expert opinion & USGS, expert & LTM, STR & Reappearance & Long & Transient & High \\
\hline Hypsypops & rubicundus & Photos & MBA & CBS & Reappearance & Short & Transient & Low \\
\hline Kelletia & kelletii & $\begin{array}{l}\text { Expert opinion, photos, } \\
\text { data }\end{array}$ & Expert & LTM, STR & Increase & Long & Persistence & High \\
\hline Laminaria & farlowii & Photos & PISCO & LTM & Reappearance & Short & Transient & High \\
\hline Leptosynapta & albicans & Expert opinion & Expert & STR & Reappearance & Long & Transient & Low \\
\hline Lobatus & galeatus & Data & $\mathrm{CNH}$ & CBS & Expansion & Short & Arrival & High \\
\hline Lovenia & cordiformis & Photos & PISCO & STR & Extension & Short & Arrival & Moderate \\
\hline Lytechinus & pictus & Photos & PISCO, MexCal & LTM, STR & Increase & Long & Arrival & Moderate \\
\hline Malacoplax & californiensis & CASIZ \#222878 & ESNERR & LTM & Expansion & Short & Arrival & High \\
\hline Medialuna & californiensis & Data & $\mathrm{CNH}$ & CBS & Contraction & Long & $\begin{array}{l}\text { Population } \\
\text { decrease }\end{array}$ & Moderate \\
\hline Paralabrax & clathratus & Photos & Expert & LTM & Increase & Short & $\begin{array}{l}\text { Population } \\
\text { increase }\end{array}$ & High \\
\hline Phyllorhiza & punctata & Photos & TRNERR & LTM & Reappearance & Short & Transient & High \\
\hline Pseudosquillopsis & marmorata & Data & ESNERR & STR & New habitat & Short & Arrival & High \\
\hline Semicossyphus & pulcher & Photos & PISCO & LTM, STR & Increase & Short & $\begin{array}{l}\text { Population } \\
\text { increase }\end{array}$ & High \\
\hline Sphoeroides & annulatus & Data & MexCal, CNH & STR, CBS & Reappearance & Short & Transient & High \\
\hline Spirobranchus & spinosus & Photos & Expert & STR & Extension & Long & $\begin{array}{l}\text { Population } \\
\text { increase }\end{array}$ & High \\
\hline Uca & princeps & Photos, expert opinion & TRNERR, expert & $\begin{array}{l}\text { LTM, STR, } \\
\text { CBS }\end{array}$ & Expansion & Long & Arrival & High \\
\hline
\end{tabular}

LTM long-term monitoring, STR short-term research, CBS community-based science

Fig. 3), which are increasing in frequency, use the same temperature data but may not convey the same message. Our strategy of providing both the total number of MHW days and non-MHW days, all of which are above the 90th percentile threshold, allows for a more holistic view of water temperature anomalies.

\section{Field observations and ranges}

We noted 29 species from central California to Baja California that responded in various ways to the warm water anomalies of 2013-2018. Detecting species redistributions is difficult but necessary to understand range dynamics, changing ecological 


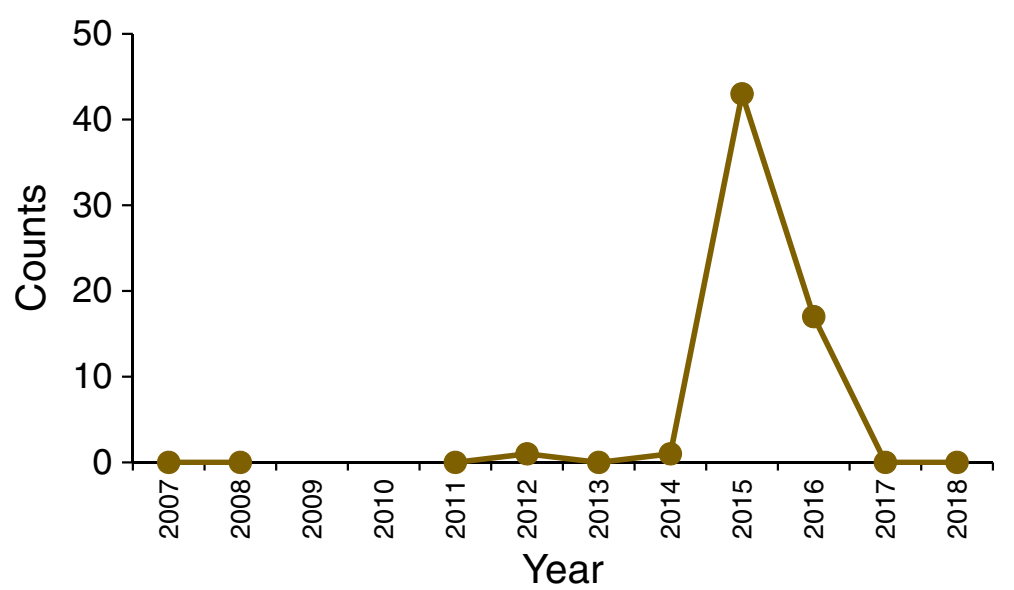

Fig. 4 Counts of Laminaria farlowii at a PISCO study site in Monterey Bay (Siren), surveyed once annually each summer from 2007 to 2018 (no data 2009, 2010). Annual counts represent the total number of $L$. farlowii observed on six $30 \times 2 \mathrm{~m}$ swath transects, two each at depths of 20 , 12.5 , and $5 \mathrm{~m}$ (i.e., $360 \mathrm{~m}^{2}$ surveyed per year). This species briefly reappeared at its northern range endpoint during the warm water event

interactions, and their consequences (e.g., Poloczanska et al. 2016, Bonebrake et al. 2018, Donelson et al. 2019). Range shifts, like invasions, add new species into an existing community. These new species may alter existing habitat as ecosystem engineers (Crooks 2002), alter competitive interactions (Byers 2009), act as important predators (Albins and Hixon 2013), or serve as important prey.

For all seven species designated as range expansions, few individuals were observed despite ongoing monitoring efforts, suggestive of a recent shift northward. These species are conspicuous enough that they would have been detected had they arrived prior to the 2013-2018 warm water events, and are thus likely to be recent expansions.

Range extensions represent range shifts that occurred in the past and were not immediately detected. The serpulid worm Spirobranchus spinosus was observed north of its published range at multiple locations in 2010 and 2011, prior to the 2013-16 warm water anomalies. This is a distinctive worm but very rare north of Point Conception, and cryptic in its use of habitat. It is possible this species has been present at very low numbers for decades but went undetected. Lovenia cordiformis was also categorized as a range extension for two reasons: heart urchins, while unique in appearance, are often

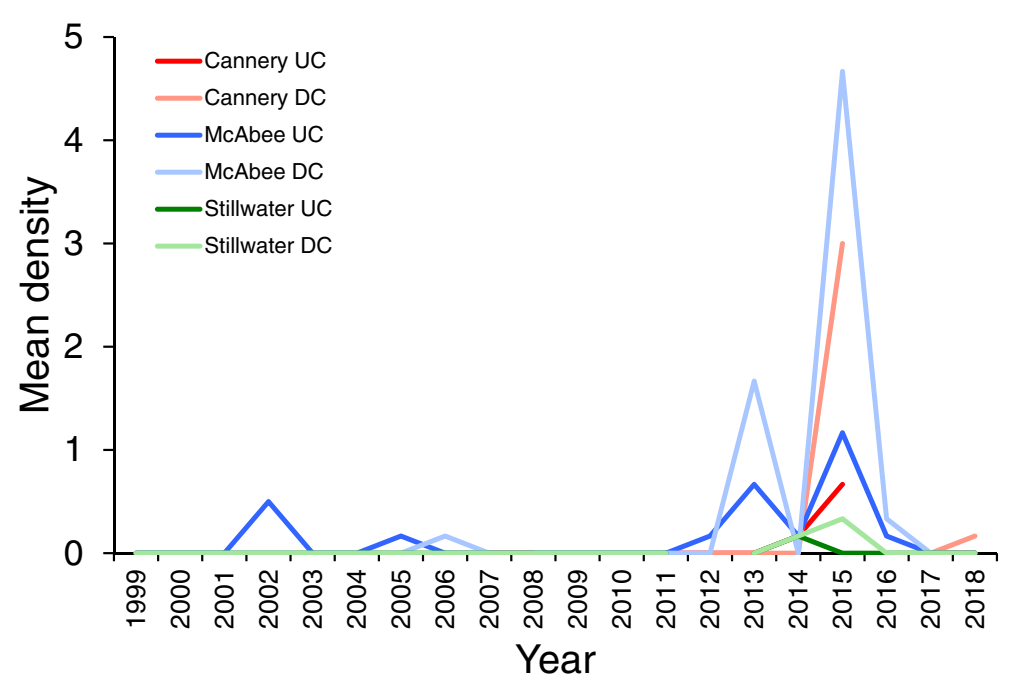

Fig. 5 Mean density of Aplysia californica at PISCO study sites in the bays of Monterey (Cannery and McAbee) and Carmel (Stillwater) from 1999 to 2018. Density calculated using count data from six $30 \times 2 \mathrm{~m}$ swath transects, two each at depths of $20,12.5$, and $5 \mathrm{~m}$ ( $360 \mathrm{~m}^{2}$ total), surveyed once annually during the summer. Within a site, upcoast (UC) and downcoast (DC) survey locations were separated by $150-300 \mathrm{~m}$. This species briefly increased in abundance during the warm water event 
buried in sand and cryptic, and both recreational and scientific divers in central California rarely dive in or monitor, respectively, sandy habitats. It is possible for both these reasons that Lovenia was present prior to the warm water anomalies but was undetected.

Recent reappearances may be linked to warm water events (Goddard et al. 2018, Williams et al. 2018), or they may occur as part of the natural dynamics of source and sink populations, coupled with irregular patterns near range endpoints (Lonhart 2009). Laminaria farlowii is a large and conspicuous kelp, and was described from specimens collected in Monterey Bay at the close of the $19^{\text {th }}$ century. Common in southern California, a valid specimen was not collected and identified north of Point Conception until 2014, despite annual surveys by PISCO since 1999. This kelp was common at only one study site in Monterey Bay in 2015, then declined in 2016. The reappearance of this kelp was facilitated by spore dispersal, since this species lacks buoyant pneumatocysts that other kelps use to drift tens of kilometers. A similar case can be made for northward-flowing currents transporting $H$. rubicundus larvae beyond Point Conception. In contrast, two cryptic invertebrates (brachiopod and sea cucumber) also re-appeared, both re-discovered in Elkhorn Slough, yet very little is known about these species in central California and they are not likely to be detected except by experts (sea cucumber) or using intensive sampling efforts (brachiopod). In some cases (e.g., Finescale Triggerfish and possibly Bullseye Puffer), reappearances may occur regularly with warm water anomalies as these species move northward with poleward flow of warm waters. Love (2011) noted Finescale Triggerfish were common off southern California during the 1982-83 El Niño, then dropped in subsequent years, but were expected to increase when conditions warmed again.

At the northern range limit of a species, sustained MHWs may cause local increases in recruitment from southern source populations, local reproductive success, and survivorship (Zacherl et al. 2003, Harley et al. 2006, Lonhart 2009). We suggest that under a warming event of sufficient duration ( $>1$ year), temperatures at the range edge become more similar to the center of the distribution, which in turn can facilitate survival of larvae derived from central populations colonizing edge populations (Molinos et al. 2017), or the warming allows local reproductive efforts to finally succeed or to increase substantially. The seven species that increased in central CA are much more abundant in southern $\mathrm{CA}$, and are considered warm-temperate or sub-tropical species. Except for A. californica and P. clathratus, Monterey Bay represents the northern range end point for these species, and historically they increase during El Niño events (SIL pers. obs.). Annual LTM data collected by PISCO indicate a weak presence of $A$. californica in central
California prior to the onset of the warm-water Blob and the 2015-16 ENSO event. A. californica generally live 1 year (Audesirk 1979, Stommes et al. 2005), so those seen in 2013 had recruited in 2012, prior to the onset of the Blob. The population of A. californica in central California has increased noticeably in the 2010s (Fig. 4), and this is likely due to local reproduction and recruitment rather than dispersal of larvae from southern California northward to central California. The population of $A$. californica appears to be self-sustaining in central California and may serve as a source for larvae to northern latitudes, transported pole-ward by the Davidson Current (Guo et al. 2014).

Shallow-water species along the coastline of CA, BC, and BCS shift ranges latitudinally because much of the coastline runs north-south. There is, however, another possibility: shifting into a new habitat. Two open-coast species, one nudibranch (Flabellina iodinea) and one mantis shrimp (Pseudosquillopsis marmorata), were reported for the first time in Elkhorn Slough, an estuary. It is unclear if this shift to a new habitat represents insipient colonization or is a short-term aberration due to an abundance of larvae along the coast during the warm water anomalies. Further monitoring is necessary to determine persistence, and in particular during normal or cool-water years.

The Halfmoon (Medialuna californiensis) appears to be absent from a large portion of its southern range along the tip of the Baja Peninsula, which may represent the initiation of a range contraction. Existing efforts emphasize reporting range shift expansions/extensions, which are based on specimens and observations. Contractions, which are also likely to occur with increasing frequency this century, receive much less attention and are more difficult to monitor. Lack of evidence is a particular issue, since not seeing a species could be due to sampling effort and error, and as a population declines near its southern range, the remaining individuals will be patchy and rare, making them more difficult to detect. The Halfmoon is an easy to identify fish that swims in the water column near kelp forests, and is monitored by numerous science programs, increasing the likelihood that a real range contraction can be monitored and verified in the coming years.

There are multiple potential mechanisms that can facilitate range shifts. Pelagic larvae are often considered a primary means of dispersal, and can lead to extralimital transport. Along the northeastern Pacific, entrainment of larvae beyond their known geographic northern limit is presumably a regular occurrence, and normally these larvae are unable to survive, except during warm water anomalies, which can increase the extent of suitable conditions for larval transport, survival, and even settlement. With the exception of Balistes polylepis and 
possibly Sphoeroides annulatus, all of the species reported here either are incapable of long-distance travel as adults or the adults can travel great distances but the new detections were of juveniles, not adults (e.g., Chromis punctipinnis, Hypsypops rubicundus, Paralabrax clathratus, and Semicossyphus pulcher). In addition to passive dispersal in the water column, drifting while attached to buoyant material (e.g., kelp, wood) can occur, as can hull-fouling of vessels and transport of larvae in ballast water. We consider it unlikely that humanmediated transport contributed to these range shifts, although one of the specimens of Pseudosquillopsis marmorata was found in a commercial oyster bed in Tomales Bay. It is unclear if its presence was due to transport with aquaculture infrastructure or was due to settlement selection by larvae during the 1991-2 ENSO. With the exception of San Francisco Bay, central California has only small ports and harbors servicing private sail boats and a small commercial fishing fleet. Ballast water transport is not an issue except in San Francisco Bay, and while hull-fouling of small boats may have facilitated some species invasions in Monterey Bay (e.g., Undaria pinnatifida and Watersipora sp.), there are no known range shifts of native species found only in central California harbors.

Twenty of the species redistributions presented here were made by professional biologists conducting LTM surveys or STR. From 2014 to 2018 species were clearly extending northward along the eastern Pacific (e.g., Cavole et al. 2016; Goddard et al. 2016; Goddard et al. 2018; Sanford et al. 2019), although some were also moving southward (Williams et al. 2018). Even for professionals, detecting a range shift can be difficult, effort can be uneven, and chance detections are idiosyncratic. We know of no LTM programs in CA, BC or BCS focused solely on range shift ecology. Przeslawski et al. (2012) recommend sampling at multiple locations along the range edge to determine if there has been a range shift, and not rely on a single site or a specific but small area. However, it is important to recognize that this method generates a snapshot, since surveys will occur over a broad spatial extent (i.e. multiple locations along and beyond the current known range margin) in a short time period. This is fundamentally different than being at one site for a long time and noting when a species is detected, as was the case for several of the range expansions in this study. Describing the leading edge, as advocated by Przeslawski et al. (2012), is likely a task better suited to amateur naturalists in CBS programs, where numerous dispersed observers at all times of the year are likely to detect species throughout their expanded range (Dickinson et al. 2010). In contrast, LTM programs and STR projects at fixed locations may detect a new species as the leading edge moves through the monitoring site, but will be ineffective at characterizing the distribution of the species in its expanded range.

As climate change continues, and the frequency and intensity of warm water anomalies increase, we expect ongoing range shifts along the entire eastern Pacific Ocean and concomitant changes to community composition, structure, function and resilience (Bonebrake et al. 2018). Species from subtropical and warm temperate systems will continue to shift to cold temperate systems, and kelp forest communities in southern and central CA may become tropicalized (Verges et al. 2019). Novel tropic interactions with expanding tropical species can have strong effects, leading to increased herbivory and loss of kelp (Wernberg et al. 2013; Verges et al. 2016). Such dramatic effects have been sporadic in southern CA, BC and BCS, usually associated with ENSO events (e.g., Dayton and Tegner 1984). But given the recent trend in more frequent warm water events, the species presented in this study and those from similar reports along the eastern Pacific, are likely the vanguard of tropicalizing species that will alter all coastal marine communities in the very near future.

\section{Additional file}

Additional file 1: This supplement includes detailed information on each of the 29 species, their historic ranges, their current ranges, how the species was reported by observers, which sampling methods the observers used, and comments by the authors. (DOCX $38 \mathrm{~kb}$ )

\section{Abbreviations}

BC: Baja California; BCS: Baja California Sur; CA: California; CAS: California Academy of Sciences; CBS: Community-based science; $\mathrm{CNH}$ : Coupled Natural Human Systems; COBI: Community and Biodiversity; ENSO: El Niño Southern Oscillation; ESNERR: Elkhorn Slough National Estuarine Research Reserve; HMS: Stanford University Hopkins Marine Station; LTM: Long-term monitoring; MBA: Monterey Bay Aquarium; MBNMS: Monterey Bay National Marine Sanctuary; MexCal: Monitoring Ecosystems Across the Californias; MHW: Marine heatwave; MPA: Marine protected area; NERR: National Estuarine Research Reserves; OR: Oregon; PISCO: Partnership for Interdisciplinary Studies of Coastal Oceans; SST: Sea surface temperature; STR: Short-term research; TRNERR: Tijuana River National Estuarine Research Reserve; UABC: Universidad Autónoma de Baja California; YOY: Young-of-theyear

\section{Acknowledgements}

We wish to thank the following field biologists and experts that provided data: R. Caldwell, M. Carr, K. Chan, S. Fork, C. Gaylord, M. Guardino, L. Harris, G. Hendler, B. Hughes, G. Jensen, K. Johnson, M. Kenner, C. King, J. Lavan, R. Lea, S. Lindstrom, D. Malone, T. McHugh, K.A. Miller, R. Mooi, A. Morgan, J. Nichols, K. Parker, J. Pearse, K. Powell, J. Sadowski, M. Silberstein, J. Smith, and K. Wasson. This study utilized data collected by the Partnership for Interdisciplinary Studies of Coastal Oceans: a long-term ecological consortium funded by the David and Lucile Packard Foundation and the Gordon and Betty Moore Foundation. We are grateful to all the people involved in the ongoing effort to maintain long-term ecological monitoring programs such as PISCO, MexCal, COBI-Stanford CNH, and special thanks to SCPP Buzos y Pescadores de la Baja California, SCPP Ensenada and SCPP La Bocana. The insightful comments of two anonymous reviewers are deeply appreciated. The scientific results and conclusions, as well as any views or opinions expressed herein, are those of the authors and do not necessarily reflect the views of NOAA or the Department of Commerce. 


\section{Authors' contributions}

All authors collected and analyzed data. SIL wrote the initial manuscript. All authors contributed to the manuscript. All authors read and approved the final manuscript.

\section{Funding}

Monterey Bay National Marine Sanctuary and Elkhorn Slough National Research Reserve supported SIL and RJ, respectively. Tijuana River National Estuarine Research Reserve, California Coastal Conservancy, and the San Diego Foundation supported JAC and JL. The Marisla Foundation, Walton Family Foundation, NSF CNH DEB 1212124, UC MexusConacyt 17-117 and UABC 19va-385 supported RBL.

\section{Availability of data and materials}

The raw data used to generate Figs. 4 and 5 are available in the DataOne repository (https://search.dataone.org/data).

\section{Ethics approval and consent to participate}

Not applicable.

\section{Consent for publication}

Not applicable.

\section{Competing interests}

The authors declare that they have no competing interests.

\section{Author details}

${ }^{1}$ Monterey Bay National Marine Sanctuary, National Ocean Service, NOAA. 110 McAllister Way, Santa Cruz, CA 95060, USA. ${ }^{2}$ Elkhorn Slough National Estuarine Research Reserve, 1700 Elkhorn Road, Watsonville, CA 95076, USA. ${ }^{3}$ Facultad de Ciencias Marinas, Universidad Autónoma de Baja California, Carretera Transpeninsular 3917, Colonia Playitas C.P., 22860 Ensenada, Baja California, México. ${ }^{4}$ Tijuana River National Estuarine Research Reserve, 301 Caspian Way, Imperial Beach, CA 91932, USA.

Received: 30 January 2019 Accepted: 5 June 2019

Published online: 18 July 2019

\section{References}

Albins MA, Hixon MA. Worst case scenario: potential long-term effects of invasive predatory lionfish (Pterois volitans) on Atlantic and Caribbean coral-reef communities. Environ Biol Fish. 2013;96(10-11):1151-7.

Audesirk TE. A field study of growth and reproduction in Aplysia californica. Biol Bull. 1979:157(3):407-21.

Bartley TJ, McCann KS, Bieg C, Cazelles K, Granados M, Guzzo MM, et al. Food web rewiring in a changing world. Nat Ecol Evo. 2019;3(3):345-54.

Bates AE, Pecl GT, Frusher S, Hobday AJ, Wernberg T, Smale DA, et al. Defining and observing stages of climate-mediated range shifts in marine systems. Glob Environ Chang. 2014;26:27-38.

Beas-Luna R, Novak M, Carr MH, Tinker MT, Black A, Caselle JE, et al. An online database for informing ecological network models: http://kelpforest.ucsc.edu. PLoS One. 2014; doi.org/10.1371/journal.pone.0109356. Accessed 13 June 2019.

Blanchette CA, Miner CM, Raimondi PT, Lohse D, Heady KEK, Broitman BR. Biogeographical patterns of rocky intertidal communities along the Pacific coast of North America. J Biogeogr. 2008;35(9):1593-607.

Bond NA, Cronin MF, Freeland H, Mantua N. Causes and impacts of the 2014 warm anomaly in the NE Pacific. Geophys Res Lett. 2015;42(9):3414-20.

Bonebrake TC, Brown CJ, Bell JD, Blanchard JL, Chauvenet A, Champion C, et al. Managing consequences of climate-driven species redistribution requires integration of ecology, conservation and social science. Biol Rev. 2018;93: 284-305.

Byers JE. Competition in marine invasions. In: Rilov G, Crooks JA, editors. Biological invasions in marine ecosystems: ecological, management, and geographic perspectives. Ecological studies. Berlin: Springer; 2009. p. 245-60.

Caffrey J, Brown M, Tyler WB, Silberstein M. Changes in a California estuary: a profile of Elkhorn Slough. Moss Landing: Elkhorn Slough Foundation; 2002. p. 280.

Cavole L, Demko A, Diner R, Giddings A, Koester I, Pagniello C, et al. Biological impacts of the 2013-2015 warm-water anomaly in the Northeast Pacific: winners, losers, and the future. Oceanography. 2016;29(2):273-85.
Crooks JA. Characterizing ecosystem-level consequences of biological invasions: the role of ecosystem engineers. OIKOS. 2002;97(2):153-66.

Dayton PK, Tegner MJ. Catastrophic storms, El Niño, and patch stability in a southern California kelp community. Science. 1984;224(4646):283-5.

Di Lorenzo E, Mantua N. Multi-year persistence of the 2014/15 North Pacific marine heatwave. Nat Clim Chang. 2016 Nov;6(11):1042-8.

Di Minin E, Tenkanen $\mathrm{H}$, Toivonen T. Prospects and challenges for social media data in conservation science. Front Environ Sci. 2015;3(63):1-6.

Dickinson JL, Shirk J, Bonter D, Bonney R, Crain RL, Martin J, et al. The current state of citizen science as a tool for ecological research and public engagement. Front Ecol Environ. 2012;10(6):291-7.

Dickinson JL, Zuckerberg B, Bonter DN. Citizen science as an ecological research tool: challenges and benefits. Ann Rev Ecol Evol Syst. 2010;41:149-72.

Donelson JM, Sunday JM, Figueira WF, Giatán-Espitia JD, Hobday AJ, Johnson CR, et al. Understanding interactions between plasticity, adaptation and range shifts in response to marine environmental change. Phil Trans Roy Soc B. 2019;374(1768):1-14.

Edwards MS, Hernández-Carmona G. Delayed recovery of giant kelp near its southern range limit in the North Pacific following El Niño. Mar Biol. 2005;147:273-9.

Feeney RF, Lea RN. Records of Wahoo, Acanthocybium solandri (Scombridae), from California. Bull So Cal Acad Sci. 2016;115(3):198-200.

Frölicher TL, Fischer EM, Gruber N. Marine heatwaves under global warming. Nature. 2018;560:360-4.

Gaston KJ. Geographic range limits: achieving synthesis. Proc Biol Sci. 2009; 276(1661):1395-406.

Gaylord B, Gaines SD. Temperature or transport? Range limits in marine species mediated solely by flow. Am Nat. 2000;155(6):769-89.

Gilman SE, Urban MC, Tewksbury J, Gilchrist GW, Holt RD. A framework for community interactions under climate change. Trends Ecol Evol. 2010;25(6): 325-32.

Goddard JHR, Treneman N, Pence WE, Mason DE, Dobry PM, Green B, et al. Nudibranch range shifts associated with the 2014 warm anomaly in the Northeast Pacific. Bull So Cal Acad Sci. 2016;115(1):15-40.

Goddard JHR, Treneman N, Prestholdt T, Hoover C, Green B, Pence WE, et al. Heterobranch Sea slug range shifts in the Northeast Pacific Ocean associated with the 2015-16 El Niño. Proc Cal Acad Sci. 2018:65(3):107-31.

Guo L, Chai F, Xiu P, Xue H, Rao S, Liu Y, et al. Seasonal dynamics of physical and biological processes in the Central California current system: A modeling study. Ocean Dyn. 2014;64(8):1137-52.

Harley CDG, Hughes AR, Hultgren KM, Miner BG, Sorte CJB, Thornber CS, et al. The impacts of climate change in coastal marine systems. Ecol Lett. 2006;9: $228-41$.

Hiscock K, Southward A, Tittley I, Hawkins S. Effects of changing temperature on benthic marine life in Britain and Ireland. Aquat Conserv-Mar Freshw Ecosyst. 2004;14(4):333-62.

Hobday AJ, Alexander LV, Perkins SE, Smale DA, Straub SC, Oliver ECJ, et al. A hierarchical approach to defining marine heatwaves. Prog in Oceanog. 2016; 141:227-38.

Hobday AJ, Oliver ECJ, Sen Gupta A, Benthuysen JA, Burrows MT, Donat MG, et al. Categorizing and naming marine heatwaves. Oceanog. 2018;31(2):162-73. Jacox MG, Alexander MA, Mantua NJ, Scott JD, Hervieux G, Webb RS, et al. Forcing of multiyear extreme ocean temperatures that impacted California Current living marine resources in 2016. Bull Am Meteor Soc. 2018;99:S27-33.

Lonhart SI. Natural and climate change mediated invasions. In: Rilov G, Crooks JA, editors. Biological invasions in marine ecosystems: ecological, management, and geographic perspectives. Ecological studies. Berlin: Springer; 2009. p. 57-69.

Lonhart SI, Tupen JW. New range records of 12 marine invertebrates: the role of El Niño and other mechanisms in southern and Central California. Bull So Cal Acad Sci. 2001;100(3):238-48.

Love MS. Certainly more than you want to know about the fishes of the Pacific Coast: a postmodern experience. Santa Barbara: Really Big Press; 2011. p. 649.

Molinos JG, Burrows MT, Poloczanska ES. Ocean currents modify the coupling between climate change and biogeographical shifts. Sci Rep. 2017;7(1332):1-9.

Pecl GT, Araujo MB, Bell JD, Blanchard J, Bonebrake TC, Chen IC, et al. Biodiversity redistribution under climate change: impacts on ecosystems and human well-being. Science. 2017;355(6332):1-9.

Pinsky ML, Worm B, Fogarty MJ, Sarmiento JL, Levin SA. Marine taxa track local climate velocities. Science. 2013;341(6151):1239-42.

Poloczanska ES, Burrows MT, Brown CJ, Molinos JG, Halpern BS, Hoegh-Guldberg $\mathrm{O}$, et al. Responses of marine organisms to climate change across oceans. Front Mar Sci. 2016;3(62):1-21 doi.org/10.3389/fmars.2016.00062. 
Przeslawski R, Falkner I, Ashcroft MB, Hutchings P. Using rigorous selection criteria to investigate marine range shifts. Estuar Coast Shelf Sci. 2012;113:205-12.

Sanford E, Sones JL, García-Reyes M, Goddard JHR, Largier JL. Widespread shifts in the coastal biota of northern California during the 2014-2016 marine heatwaves. Sci Rep. 2019;9(4216):1-14.

Smale DA, Wernberg T, Oliver ECJ, Thomsen M, Harvey BP, Straub SC, et al. Marine heatwaves threaten global biodiversity and the provision of ecosystem services. Nat Clim Chang. 2019;9(4):306-12.

Stommes D, Fieber LA, Beno C, Gerdes R, Capo TR. Temperature effects on growth, maturation, and lifespan of the California Sea hare (Aplysia californica). Contemp Top Lab Anim Sci. 2005;44(3):31-5.

Thompson AR, Schroeder ID, Bograd SJ, Hazen EL, Jacox MG, Leising A, et al. State of the California Current 2017-18: still not quite normal in the north and getting interesting in the south. CalCOFI Rep. 2018;59:1-66.

Tingley MW, Beissinger SR. Detecting range shifts from historical species occurrences: new perspectives on old data. Trends Ecol Evol. 2009;24(11): 625-33.

Valentine JW. Numerical analysis of marine molluscan ranges on the extratropical northeastern Pacific shelf. Limnol Oceanog. 1966;11:198-211.

Verges A, Doropoulos C, Malcolm HA, Skye M, Garcia-Pizá M, Marzinelli EM, et al. Long-term empirical evidence of ocean warming leading to tropicalization of fish communities, increased herbivory, and loss of kelp. Proc Nat Acad Sci. 2016;113(48):13791-6.

Verges A, McCosker E, Mayer-Pinto M, Coleman MA, Wernberg T, Ainsworth T, et al. Tropicalisation of temperate reefs: implications for ecosystem functions and management actions. Funct Ecol. 2019:1-14 https://doi.org/10.1111/ 1365-2435.13310.

Wernberg T, Smale DA, Tuya F, Thomsen MS, Langlois TJ, de Bettignies T, et al. An extreme climatic event alters marine ecosystem structure in a global biodiversity hotspot. Nat Clim Chang. 2013;3:78-82.

Williams JP, Williams CM, Blanchette CA, Claisse JT, Pondella DJ, Caselle JE. Where the weird things are: a collection of species range extensions in the Southern California Bight. Bull So Cal Acad Sci. 2018;117(3):189-202.

Zacherl D, Gaines SD, Lonhart SI. The limits to biogeographical distributions: insights from the northward range extension of the marine snail, Kelletia kelletii (Forbes, 1852). J Biogeogr. 2003;30(6):913-24.

Zedler JB, Nordby CS, Kus BE. The ecology of Tijuana estuary, California: a national estuarine research reserve. San Diego: San Diego State University; 1992. p. 151.

\section{Publisher's Note}

Springer Nature remains neutral with regard to jurisdictional claims in published maps and institutional affiliations.

Ready to submit your research? Choose BMC and benefit from:

- fast, convenient online submission

- thorough peer review by experienced researchers in your field

- rapid publication on acceptance

- support for research data, including large and complex data types

- gold Open Access which fosters wider collaboration and increased citations

- maximum visibility for your research: over $100 \mathrm{M}$ website views per year

At $\mathrm{BMC}$, research is always in progress.

Learn more biomedcentral.com/submissions 